\title{
Selecting the Most Adequate Bedding Material for Broiler Production in Brazil
}

-Author(s)
Garcia RG ${ }^{1}$
Almeida Paz ICL1
Caldara FR ${ }^{1}$
Nääs IA 1
Pereira DF²
Ferreira VMOS 1
1 College of Animal Science, Federal University
of Grande Dourados - UFGD, Dourados,
MS, Brazil
2 Experimental Unit of Tupã, State University
of São Paulo - UNESP, Tupã, SP, Brazil

\section{Mail Adress}

College of Animal Science, Federal University of Grande Dourados

Dourados, MS, Brazil

Email: RodrigoGarcia@ufgd.edu.br

\section{Eeywords}

Alternative bedding material, broiler production, multiple criteria analysis, AHP.

\begin{abstract}
Broiler chicken production is widely dispersed across the globe, and one important issue for growers is the selection of adequate bedding material, as the availability and price of substrates varies among countries and regions within a same country. This study aimed at applying a multiple criteria analysis approach for the selection of the most appropriate bedding material for broiler production. Based on field research data and growers' experience, the most desirable characteristics of a litter material were chosen as the main criteria. The selected materials were wood shavings, rice husks, chopped Napier grass (Pennisetum pupureum), 50\% sugar cane bagasse (Saccharum L.) plus 50\% wood shavings, 50\% sugar cane bagasse (Saccharum L.) plus $50 \%$ rice husks, and pure sugar cane bagasse (Saccharum L.). The analytical hierarchy process (AHP) was applied for selecting the most suitable bedding material. Validation was performed using data from previous studies carried out in central-western Brazil on the effects of different types of bedding material on broiler carcass quality. Considering the selected criteria, several bedding materials were tested and ranked, and the results showed that wood-shavings litter was the best option (weight $=0.28$ ), followed by rice husks (weight $=0.24$ ). All other tested alternatives presented lower scores and were, therefore, not considered for use. The AHP approach was found to be an efficient tool to select the most appropriate litter material under specific scenarios.
\end{abstract}

\section{INTRODUCTION}

Bedding material acquisition and litter management are important issues for broiler producers. The sustainability of broiler production requires bedding material to be environmentally friendly, and the replacement of litter needs to be efficient and cost-effective in order to be implemented by growers in a profitable way (Mayne et al., 2007; Bilgili et al., 2009). This requires the availability of alternative bedding sources, as well as good understanding of how to reduce $\mathrm{NH}_{3}$ emissions in reused litter. Managing litter moisture is challenging in reused litter, especially during the last weeks of the growout. The important factors that influence moisture in the rearing environment include short downtimes between flocks, partial-house brooding, evaporative cooling systems, and poor drinking water management (Bilgili et al., 2009). Health issues and the incidence of breast burns and blisters, leg abnormalities, and footpad lesions are reported in the literature as partially due to poor litter conditions (Benabdewelil \& Ayach, 1996).

Amongst the available multi-attribute approaches, the analytic hierarchy process (AHP) is the best because it is capable of combining different types of criteria in a multi-level decision structure in order to obtain a single score for each alternative and to rank the proposed alternatives overall. Several studies have been published on different AHP scenarios and arrays, and the conclusions support the suitability 
of this analysis for the selection of specific criteria (Benabdewelil \& Ayach, 1996; Karami, 2006; Omkarprasad \& Sushil, 2006; Halmar et al., 2009; Almeida Paz et al., 2010).

This study aimed at applying the AHP approach for the selection of the most appropriate bedding material considering all restrictions and benefits to the producer.

\section{MATERIALS AND METHODS}

Applying AHP model involves the following steps: (a) structuring the selection problem, (b) identifying the technological options, (c) identifying the applicable criteria, (d) developing the weighting schemes, and (e) ranking the management or technological options. These steps are detailed below.

\section{Structuring the selection} of the appropriate broiler bedding material and identifying the options

Identifying and structuring the objective of selecting the proper broiler bedding material required careful literature investigation to provide the basis for quantitative modeling. The fundamental challenge was to identify the attributes that producers genuinely consider important because the objective hierarchies should be constructed according to this classification (Rosado Jr. et al., 2011). In this specific study, the main goal was to select the appropriate broiler bedding material for a specific scenario. The attributes were selected based on the criteria broiler growers generally use when purchasing bedding material and on previous research results (Bowers et al., 2003; Bilgili et al., 2009; Macklin \& Krehling, 2010).

Choosing a conventional or alternative bedding material involves selecting from a set of available options, each of which may fulfill some or all of the desired criteria. Although there theoretically are several types of adequate bedding alternatives, many options are often considered to be untenable due

\section{Lerel 1 - Goal}

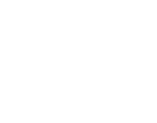

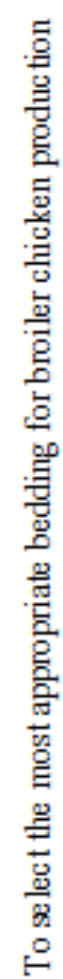

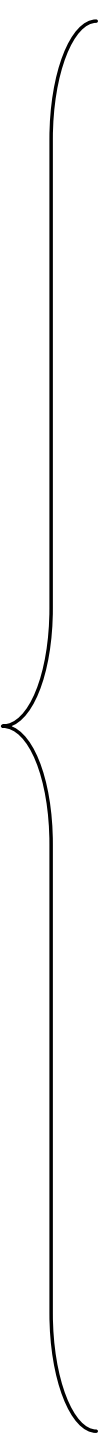

to technical restrictions (Macklin et al., 2005; Mayne et al., 2007; Bilgili et al., 2009; Garcia et al., 2010).

\section{Identifying the applied selection criteria}

The selected criteria were chosen based on findings published in the current literature (Bowers et al., 2003; Mayne et al., 2007; Bilgili et al., 2009; Freitas et al., 2009) and on growers' experience and knowledge. The scheme of the system was designed using the following three distinct levels: level 1 represented the goal, level 2 represented the most important characteristic of a bedding material, and level 3 represented the related characteristics that fulfill level 2 (Figure 1).
Lerel2

Cost

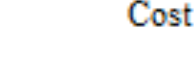

Availability

Easiness of handling \{

Possibility of reuse

Absorption capacity

Ability of avoiding compacting

Low fermentation

Environmental impact
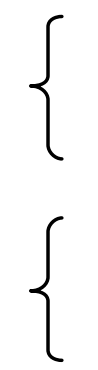

Proximity of the supplier
Reliability of supply
Quantity
Quality

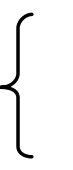

\section{Transporting Remova1 \\ Decompacting Handling}

Number of flocks<smiles>CCCCC</smiles>
Capability of preserving quality Low level of contamination Easiness of treatment between flocks

\section{Good welfare conditions}

Less footpad dermatitis

Less breast damage

Less claw dermatitis Less bruising

Low ammonia emission Low microbial development

Waste Possibility of other uses

\section{Performance}

Carcass yield

Figure 1 - Schematic description of the criteria used for selecting the most appropriate bedding material for broiler chicken production. 
where $w$ is the weight of importance and the

\section{Developing the weighting schemes and ranking the options}

The purpose of the AHP is to provide a vector of weights expressing the relative importance of the alternatives for each criterion. The adopted scale of importance was defined according to the method described by Saaty (1977), using a 1-9 score scale for pairwise comparison (Table 1).

Table 1. Adopted scale of importance

\begin{tabular}{cl}
\hline Intensity of importance & Definition \\
\hline 1 & Equal importance \\
\hline 5 & Moderate importance \\
\hline 7 & Strong importance \\
9 & Very strong or demonstrated importance \\
$2,4,6,8$ & $\begin{array}{l}\text { Intermediate values } \\
\text { If factor i has one of the above numbers } \\
\text { assigned to it when compared to factor } \\
j, \text { then } j \text { has the reciprocal value when } \\
\text { compared with } i\end{array}$ \\
\hline
\end{tabular}

Adapted from Saaty (1977)

When the AHP approach is applied, a pairwise comparison matrix is established. The rows and columns of this matrix represent the components that belong to the same parent component in the decision hierarchy (Eq. 1). The weight of component i compared to component $\mathrm{j}$ relative to the parent component is determined using Saaty's scale (Table 1). The weight is then assigned to the $(i, j)^{\text {th }}$ position of the pairwise comparison matrix (Saaty, 1980) in order to support comparisons within a limited range, but with sufficient sensitivity. The reciprocal of the assigned number is assigned to the $(j, i)^{\text {th }}$ position. Once the pairwise comparison matrix is established, the weights of the components are calculated by solving for the eigenvector of the pairwise comparison matrix:

$\mathrm{A}=\left[\begin{array}{cccc}\text { Criterion 1 } & \text { Criterion 1 } & \text { Criterion 2 } & \text { Criterion 3 } \\ \text { Criterion 2 } & \mathrm{w}_{21} & \mathrm{w}_{12} & \mathrm{w}_{13} \\ \text { Criterion 3 } & \mathrm{w}_{31} & \mathrm{w}_{32} & \mathrm{w}_{23} \\ \ldots & \ldots & \cdots & 1 \\ \text { Criterion n } & \mathrm{w}_{n 1} & \mathrm{w}_{n 2} & \mathrm{w}_{n 3}\end{array}\right.$
criterion is more important than. Pairwise comparisons are then made between each pair of factors at a given level of the hierarchy relative to their contribution to the factor at the immediately preceding level. These pairwise comparisons yield a reciprocal $(n, n)$ matrix , where $a_{i i}=1$ (diagonal elements) and $a_{i j}=1 / a_{i j}$. Suppose that only the first column of matrix is provided to state the relative importance of factors $2,3, \ldots$, with respect to factor 1 . If the judgments were completely consistent, then the remaining columns in the matrix would be completely determined by the transitivity of the relative importance of the factors. However, there would be no consistency except for that created by setting $a_{i j}=1 / a_{i j}$. Therefore, the comparison needs to be repeated for each column of the matrix; specifically, independent judgments must be made for each pair. is consistent if and only if $\lambda_{\max }=$. However, the inequality of $\lambda_{\max }>$ always exists; therefore, the average of the remaining eigenvalues $(\lambda)$ can be used as a consistency index $\left(\mathrm{Cl}\right.$; Eq. 2), which is the difference between $\lambda_{\max }$ and divided by the normalizing factor $(n-1)$.

$$
C l=(\lambda \max -n) /(n-1)
$$

where $\mathrm{Cl}=$ consistency index; $\lambda_{\max }=$ highest eigenvalue; and $n=$ number of matrix elements.

The $\mathrm{Cl}$ of the studied problem is compared with the average random index (RI) obtained from associated random matrices of order $n$ to measure the error due to inconsistency (Saaty, 1977; Saaty, 1980). A consistency ratio $(C R=C l / R I)$ with a value $\leq 0.1$ should be maintained for the matrix to be consistent; otherwise, the pairwise comparisons should be revised. The homogeneity of factors within each group, a small number of factors in the group, and a better understanding of the decision problem would improve the consistency index.

\section{Field validation}

The validation was performed using data obtained from a field study (Caldara et al., 2009; Freitas et al., 2009; Bilgili et al., 2009; Almeida Paz et al.,
Criterion $\mathrm{n}$

$\left.\begin{array}{c}\mathrm{w}_{l n} \\ \mathrm{w}_{2 n} \\ \mathrm{w}_{3 n} \\ \cdots \\ 1\end{array}\right]$
2010) comparing six different bedding materials available in most regions of Brazil, as well as mixtures of these materials

Eq. 1 such as wood shavings, rice husks, chopped Napier grass (Pennisetum pupureum), 50\% 
sugarcane bagasse (Saccharum L.) plus 50\% wood shavings, 50\% sugarcane bagasse (Saccharum L.) plus 50\% rice husks, and pure sugarcane bagasse (Saccharum L.). The wood shavings consisted of nearly $80 \%$ of Eucaliptus saligna and $20 \%$ of other mixed woods. Chopped grass was 1 to $1.5 \mathrm{~cm}$ long, and sugarcane bagasse was 0.1 to $3 \mathrm{~cm}$ long. All tested bedding materials were applied at a depth of $10 \mathrm{~cm}$. A total of 3,240 broiler chickens (Manual, 2010) were distributed in 60 pens measuring $4.5 \mathrm{~m}^{2}$ each, each equipped with a bell drinker and a tube feeder. Flock density was 12 birds $\mathrm{m}^{-2}$, which is typical in Brazil. House side walls were covered with curtains and inside temperature was controlled using fans and foggers. Chicks were brooded using $250 \mathrm{~W}$ infrared lamps, one per pen. The lighting regime was $24 \mathrm{~h}$ of light during the entire rearing period using $40 \mathrm{~W}$ lamps, which provided an average of $22 \mathrm{Ix}$. All birds received feed and water ad libitum during the entire experimental period. The feeding program included the following three phases: a starter diet (day 1-21), a grower diet (day 22-35), and a finisher diet (day 36-42).

The following material features were studied: litter microbiological aspects, temperature, litter moisture content and caking index, ammonia emission, house temperature, bird surface and body temperatures, and bird performance (Freitas et al., 2009; Almeida Paz et al., 2010). Data were recorded during the growout period and carcass yield was evaluated at slaughter on day 42 .

Computational analysis for calculating the criteria weights and $C R$ was performed using online software MIR (2011).

\section{RESULTS AND DISCUSSION}

Local weight represents the specific importance of determined criteria as determined by the previous level of judgment when the presented alternatives are compared pairwise. The pairwise comparison started at the lowest level, which was the level 3, in order to build up the local and global weights in level 2. The global weight represents the importance of a criterion within the level 2, which may influence the goal (level 1). $C R$ values were adjusted to be acceptable ( $C R \leq$ $0.1)$, and this procedure was automatically carried out using the multi-criteria software program.

The weight results of the criteria for selecting broiler chicken bedding material show the highest value for "possibility of reuse" (weight $=0.16$ ), followed by "ease of handling" (weight $=0.15$ ) and "cost" (weight
$=0.13$ ), as shown in Table 2 . Considering those criteria and the tested types of bedding material, it can be seen that wood shavings is the alternative that offers the highest "possibility of reuse" and "ease of handling" (weight $=0.06$ ), followed by rice husks (weight $=0.05$ and 0.04 , respectively). The criteria "cost" had the highest value (weight $=0.03$ ) for chopped Napier grass (Pennisetum pupureum) and the sugarcane bagasse (Saccharum L.), while other material alternatives remained in third place (weight $=0.02$ ) .

Criteria were prioritized based on their relative importance to every other choice in their hierarchy and with respect to a dominant choice; therefore, criteria are compared relative to the goal, and the alternatives relative to each criterion. The results of the pairwise comparisons were recorded in a positive consistency matrix. The most favorable is criterion option compared to the alternatives, the higher the value of its weight. Therefore, the high value of "cost" credited to the material means that it is the less expensive bedding alternative. Attention needs to be called upon the fact that not all broiler producers have Napier grass planted on their farm but, when available, it may be the most cost-effective solution (weight $=0.03$ ); this is also applicable when considering sugarcane bagasse as bedding material (weight $=0.03$ ). None of the three highest-scoring criteria ("possibility of reuse", "ease of handling", and "cost") alone or combined was sufficient to determine the best choice of bedding material. Such calculation may require the use of a complex multiple criteria model, with extra levels included.

Although producers' primary goal is to maximize performance and carcass yield, these two criteria accounted for little in the overall decision weight, which is consistent with the results presented by Bilgili et al. (2009). These authors evaluated commercial and alternative bedding materials and found that they had little influence on broiler live performance in three successive trials. The incidence and severity of footpad dermatitis significantly varied among bedding materials, and were related to high litter moisture and caking scores. From the standpoint of preventing footpad dermatitis, the capacity of a bedding material to absorb and quickly release moisture may be its most important characteristic (Loch et al., 2011). It has been reported that wet litter conditions increase volatilization of ammonia from the litter (Nagaraj et al., 2007) and that ammonia emissions from wood shavings were $19 \%$ greater than from wheat straw around drinkers. In addition, worse caking was observed when wheat straw was used (Tasistro et al., 2007). 
Table 2 - Local weight, global weight and final score of bedding materials, considering the given weights of selection criteria .

\begin{tabular}{|c|c|c|c|c|c|c|c|}
\hline \multirow[b]{3}{*}{ Level 2 Criteria } & \multicolumn{7}{|c|}{ Alternatives of bedding material } \\
\hline & 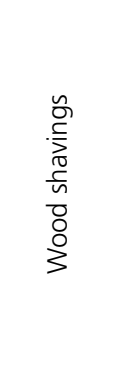 & 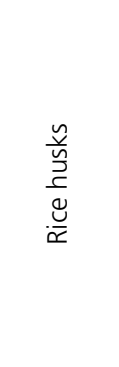 & 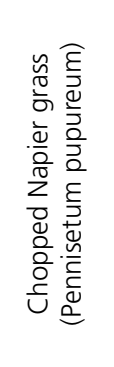 & 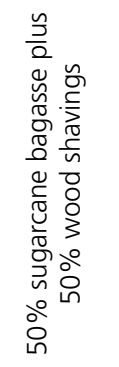 & 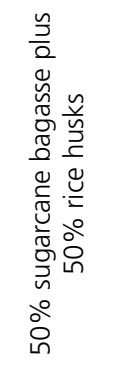 & 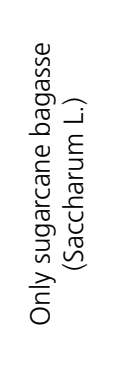 & \multirow[t]{2}{*}{ 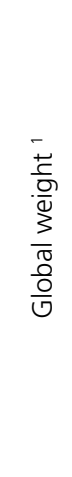 } \\
\hline & \multicolumn{6}{|c|}{ Local weight } & \\
\hline Cost & 0.02 & 0.02 & 0.03 & 0.02 & 0.02 & 0.03 & 0.13 \\
\hline Availability & 0.02 & 0.04 & 0.01 & 0.02 & 0.02 & 0.01 & 0.12 \\
\hline Ease of handling & 0.06 & 0.04 & 0.02 & 0.01 & 0.01 & 0.01 & 0.15 \\
\hline Possibility of reuse & 0.06 & 0.05 & 0.02 & 0.01 & 0.01 & 0.01 & 0.16 \\
\hline Absorption capacity & 0.03 & 0.02 & 0.01 & 0.01 & 0.01 & 0.00 & 0.08 \\
\hline Capacity to prevent caking & 0.02 & 0.02 & 0.01 & 0.01 & 0.01 & 0.00 & 0.06 \\
\hline Low fermentation & 0.02 & 0.02 & 0.01 & 0.01 & 0.01 & 0.00 & 0.06 \\
\hline Environmental impact & 0.02 & 0.01 & 0.00 & 0.01 & 0.01 & 0.00 & 0.05 \\
\hline Performance & 0.03 & 0.02 & 0.02 & 0.02 & 0.02 & 0.02 & 0.12 \\
\hline Carcass yield & 0.02 & 0.02 & 0.01 & 0.01 & 0.02 & 0.01 & 0.08 \\
\hline Final ranking ${ }^{1}$ & $0.28(1)$ & $0.24(2)$ & $0.13(3)$ & $0.13(3)$ & $0.12(4)$ & $0.10(5)$ & 1.00 \\
\hline
\end{tabular}

${ }^{1}$ The sum of the final weight scores of each alternative is equal to 1 (Saaty, 1980)

The number betweeb parentheses is the ranking of the alternatives of the each tested bedding material

A significant percentage of the crop area in Brazil is used to produce sugarcane, rice and pastures for beef cattle (Table 3). Napier grass is used for cattle grazing and accounts for the smallest harvested area among the crops used in the present study as litter material. Considering that Napier grass is not a residual product of agricultural activities, that its availability is low in the studied region, and that it has high nutritional value for beef cattle production (NRC, 1996; Fontes et al., 2005), this substrate may not be the most costeffective material to use as broiler chicken litter. The availability of sugarcane and rice varies across different regions of Brazil. In the southern region, a large percentage the planted area (nearly $45 \%$ ) is used for sugarcane, resulting in high production of bagasse. In the northern region, large areas of rice are planted, generating large quantities of this product. However, sugarcane is a seasonal crop and its accessibility and availability vary throughout the year.
Sugarcane bagasse has a high nutritional value for beef cattle (Bulle et al., 2002; Leme et al., 2003) and presents high energy value (Cortez \& Gómez, 1998; Sosa-Arnao et al., 2004). In addition, it is used for generating energy by the sugar plants and to produce ethanol, limiting its use as poultry bedding. Rice husks are available in large quantities in some regions of Brazil, where is it used as broiler litter, but the performance of flocks raised on this material is worse compared with wood shavings. Shields et al. (2004) tested four types of bedding materials and found that broilers did not present some natural behaviors, such as dust bathing, when raised on rice husks. According to those authors, dust bath is an important social behavior that helps reducing aggressive behaviors and improves general leg health conditions, leading to better mobility and better flock welfare. In addition, the cost of rice husks is higher than wood shavings in some broiler production regions (Table 3 ) where rice 
Table 3 - Percentage of harvested area of various bedding materials in Brazil (sugarcane, rice and forage grass) according to region and broiler chicken production in each region.

\begin{tabular}{lcccc}
\hline Region & Forage grass & Harvested area (\%) & Sugarcane & $\begin{array}{c}\text { Broiler chicken production } \\
\text { (million head) }\end{array}$ \\
\hline North & 0.00 & 1.05 & 20.06 & 18.96 \\
\hline Northeast & 3.06 & 9.00 & 5.93 & 97.06 \\
Southeast & 0.42 & 45.6 & 0.80 & 281.83 \\
South & 0.14 & 2.26 & 6.35 & 493.67 \\
Central West & 0.07 & 5.51 & 1.94 & 102.78 \\
\hline Brazil (Total) & 0.91 & 11.36 & 4.91 & 994.30 \\
\hline
\end{tabular}

Source: IBGE (2010)

is not intensively grown. Wood shavings are mainly a byproduct of the wood furniture industry and are available almost everywhere in Brazil. Wood shavings do not have a high energy value and are usually considered as waste, and therefore, in most regions, are considered a low cost broiler bedding material. Broiler performance and welfare were found to be improved when the birds are reared on wood shavings (Neme et al., 2000).

The final ranking of alternatives (Table 2) shows that the most appropriate broiler litter material under the studied scenario was wood shavings, followed by rice husks. Most studies comparing poultry bedding materials have reported that, when birds are reared on alternative bedding materials, their performance is equal to or worse than that of birds reared on wood shavings (Benabdewelil \& Ayach, 1996; Grimes et al., 2002). However, according to Tasistro et al. (2007), broiler mortality was not affected when nonconventional bedding materials were used, although weight gain was significantly lower when birds were reared on wheat straw relative to wood shavings.

\section{CONCLUSIONS}

The results of the present study show that the AHP model can be used as a valuable decision analysis tool for the selection of broiler bedding material under a specific scenario. Wood shavings seemed to be the best choice of bedding material for broiler producers in Central-Western Brazil.

An alternative, economical and efficient source of bedding material presenting favorable, environmentally-friendly characteristics that allows recycling or reducing waste may be needed to meet future demands of broiler producers.

\section{ACKNOWLEDGEMENTS}

The authors thank the Foundation of Support of the Development of Education, Science and Technology of the State of Mato Grosso do Sul (FUNDECT), CAPES, and the PET/MEC/SESU Program.

\section{REFERENCES}

Almeida Paz ICL, Garcia RG, Bernardi R, Nääs IA, Caldara FR, Freitas LW, Seno LO, Ferreira VMOS, Pereira DF, Cavichiolo FI. Selecting appropriate bedding to reduce locomotion problems in broilers. Brazilian Journal of Poultry Science 2010; 12: 189-195.

Benabdewelil K, Ayach A. Evaluation of alternative litter materials for poultry. Journal of Applied Poultry Research 1996; 5: 203-209.

Bilgili SF, Hess JB, Blake JP, Macklin KS, Saenmahayak B, Sibley JL. Influence of bedding material on footpad dermatitis in broiler chickens. Journal of Applied Poultry Research 2009; 18: 583-589.

Bowers BD, Hess JB, Bilgili SF, Blake JP, Eckman MK, Guertal EA. Nutrient buildup in sand litter. Journal of Applied Poultry Research 2003; 12: 522-525.

Bulle MLM, Ribeiro FG, Leme PR, Titto EAL, Lanna DPD. Desempenho de tourinhos cruzados em dietas de alto teor de concentrado com bagaço de cana-de-açúcar como único volumoso. Revista Brasileira de Zootecnia 2002; 31: 444-450.

Cortez LAB, Gómez EO. A method for energy analysis of sugarcane bagasse boilers. Brazilian Journal Chemical Engineering 1998; 15:1-4.

Fontes CAA, Oliveira RC, Erbesdobler ED, Queiroz DS, Lombardi CT. 2005. Conteúdo de energia líquida par mantença e ganho do capim-elefante e mudanças na composição corporal de novilhos em pastejo, durante estação chuvosa. Revista Brasileira de Zootecnia 2005; 34: 1711-1720.

Freitas LW, Garcia RG, Graciano JD, Amadori AH, Vargas Junior FM. Compactação da cama de frangos de corte composta por diferentes substratos. IProceedings of the $27^{a}$ Conferência FACTA de Ciência e Tecnologia Avícola; 2009; Porto Alegre, Santa Catarina. Brazil. p. 1-4, 2009.

Garcia RG, Almeida Paz ICL, Caldara FR, Nääs IA, Pereira DF, Freitas LW, Schwingel AW, Lima NDS, Graciano JD. Effect of the litter material on drinking water quality in broiler production. Brazilian Journal of Poultry Science 2010; 12: 165-169.

Grimes JL, Smith J, Williams CM. 2002. Some alternative litter materials used for growing broilers and turkeys. World's Poultry Science Journal 2002; 58:515-525.

Halmar H, Stigebrandt A, Rehbein M, McKinnon AD. Developing a decision support system for sustainable cage aquaculture. Environmental Modelling \& Software 2009; 24: 694-702.

IBGE - Instituto Brasileiro de Geografia e Estatística [citado 2010 April 26]. Disponível em: http://www.sidra.ibge.gov.br/. 
Karami E. Appropriateness of farmers' adoption of irrigation methods: The application of the AHP model. Agricultural Systems 2006; 87: 101-119.

Leme PR, Silva SL, Pereira ASC, Putrino SM, Lanna DPD, Nogueira Filho JCM. Utilização do bagaço de cana-de-açúcar em dietas com elevada proporção de concentrados para novilhos Nelore em confinamento. Revista Brasileira de Zootecnia 2003; 31: 1786-1791.

Loch FC, Oliveira MC, Silva D, Gonçalves BN, Faria BF, Menezes JFS. Quality of poultry litter submitted to different treatments in five consecutive flocks. Revista Brasileira de Zootecnia 2011; 40:1025-1030.

Macklin KS, Hess JB, Bilgili SF, Norton RA. Bacterial levels of pine shavings and sand used as poultry litter. Journal of Applied Poultry Research 2005; 14: 238-245

Macklin KS, Krehling JT. The use of metam-sodium to reduce bacteria in poultry litter. Journal of Applied Poultry Research 2010; 19: 274-278.

MIR - Make it rational[cited 2011 Nov 3]. Available from: http:// makeitrational.com/

Mayne RK, Else RW, Hocking PM. 2007. High litter moisture is sufficient to cause footpad dermatitis in growing turkeys. British Poultry Science 2007; 48:538-545.

Nagaraj M, Wilson CAP, Saenmahayak B, Hess JB, Bilgili SF. Efficacy of a litter amendment to reduce pododermatitis in broiler chickens. Journal of Applied Poultry Research 2007; 16: 255-261.

Neme R, Sakomura NK, Oliveira MDS, Longo FA, Figueiredo NA. Adição de gesso agrícola em três tipos de cama de aviário na fixação de nitrogênio e no desempenho de frangos de corte. Ciência Rural 2000; 30: 687-692.

NRC - National Research Council. Nutrient requirements of beef cattle. $7^{\text {th }}$ ed. Washington, DC; 1996.

Omkarprasad SV, Sushil K. Analytic hierarchy process: An overview of applications. European Journal of Operational Research 2006; 169: $1-29$.

Rosado Jr AG, Lobato JFP, Muller C. Building consolidated performance indicators for an agribusiness company: A case study. Revista Brasileira de Zootecnia 2011; 40: 454-461.

Ross Breeders [2010 Aprim 20]. Available from: http://www.rossbreeders. com

Saaty TL. A scaling method for priorities in hierarchical structures. Journal of Mathematics Psychology 1977; 15: 234 - 281.

Saaty TL. The analytic hierarchy process. New York: McGraw-Hill; . 1980.

Shields SJ, Garner JP, Mench JA. Dustbathing by broiler chickens: a comparison of preference for four different substrates. Applied Animal Behaviour Science 2004; 87: 69-82.

Sosa-Arnao JH, Oliveira FM, Corrêa JLG, Silva MA, Nebra SA. Sugarcane bagasse drying - a review. In: Proceedings of the $14^{\text {th }}$ International Drying Symposium; 2004;, São Paulo, SP. Brazil. p. 990-997

Tasistro AS, Ritz CW, Kissel DE. Ammonia emissions from broiler litter: response to bedding materials and acidifiers. British Poultry Science 2007; 48: $399-405$. 
